\title{
ANALISA OVERALL RESOURCE EFFECTIVENESS UNTUK MENINGKATKAN DAYA SAING DAN OPERATIONAL EXCELLENCE
}

\author{
Budi Aprina \\ Dosen Fakultas Teknik Prodi Teknik Industri Universitas Pamulang \\ Dosen00917@unpam.ac.id
}

\begin{abstract}
ABSTRAK
Penelitian ini bertujuan untuk dapat merumuskan rancangan atau metode yang diharapkan bisa dipakai untuk meningkatkan produktivitas sehingga mencapai operational excellence. Penelitian dilakukan dengan menggunakan analisa Overall Resource Effectiveness (ORE). ORE ini adalah pengembangan dari metode Overall Equipment Effectiveness. Bila dalam OEE variabel yang dihitung ada tiga variable (Availability, Performance dan Quality), sedangkan untuk ORE ada tujuh variabel (Readiness, Performance, Quality, Availability of Facility, Changeover Efficiency, Availability of Material dan Availability of Manpower). Setelah pengukuran data OEE dan ORE selesai, proses analisa dilakukan dengan proses observasi dan wawancara. Hal ini dilakukan untuk memperdetail hasil pengukuran yang sudah dilakukan. Kemudian setelah itu dibuat kerangka analisa 4M1L dan diaplikasikan dengan diagram sebab akibat (fishbone). Dari rangakaian tersebut maka akan muncul rancangan atau metode untuk meningkatkan produktivitas sehingga terwujud operational excellence. Hasil pengukuran OEE \& ORE, secara total nilai OEE dan ORE berada dibawah nilai standar (85\%). Rata-rata nilai OEE tahun 2014 $73.52 \%$ dan tahun 2015 mengalmi penurunan menjadi $69.4 \%$. Sedangkan rata-rata untuk nilai ORE tahun $2014,80.24$ dan tahun 2015 juga turun menjadi $73.38 \%$
\end{abstract}

Kata kunci : Operational Excellence, Overall Equipment Effectiveness, Overall Resource Effectivness, Produktivitas.

\section{PENDAHULUAN}

Menurut Undang-Undang Nomor 3 Tahun 2014 tentang Perindustrian, Industri adalah seluruh bentuk kegiatan ekonomi yang mengolah bahan baku dan/atau memanfaatkan sumber daya industri sehingga menghasilkan barang yang mempunyai nilai tambah atau manfaat lebih tinggi, termasuk jasa industri. Perusahaan manufaktur merupakan penopang utama perkembangan industri di sebuah negara. Perkembangan industri manufaktur di sebuah negara juga dapat digunakan untuk melihat perkembangan industri secara nasional di negara itu. Perkembangan ini dapat dilihat baik dari aspek kualitas produk yang dihasilkannya maupun kinerja industri secara keseluruhan. Industri manufaktur masa depan adalah industri-industri yang mempunyai daya saing tinggi.

Peningkatan produktivitas sangat penting untuk meningkatkan daya saing. Untuk mempunyai daya saing yang tinggi dan keunggulan operasional (Operational Excellence) maka produktivitas harus ditingkatkan Karena produktivitas sangat berkaitan erat dengan daya saing.

Pasar konstruksi dan sektor bahan bangunan Indonesia telah berkembang secara signifikan, didorong oleh pesatnya pertumbuhan pasar properti/real estate dalam negeri, peningkatan investasi swasta dan belanja pemerintah; Konstribusi sektor konstruksi terhadap produk domestik bruto (PDB) tanah air telah tumbuh dari sekitar 7,07\% di tahun 2009 menjadi $13 \%$ pada 2014 dan telah mendorong pertumbuhan industri bahan bangunan dan konstruksi Indonesia. Pasar konstruksi diproyeksikan tumbuh sebesar 14,26\% mencapai Rp 446 triliun pada tahun 2015 dan akan menjadi salah satu sektor yang paling menjanjikan berkat percepatan rencana pembangunan infrastruktur pemerintah.

PT. Surya Toto Indonesia yang bergerak dalam bidang manufaktur khususnya plumbing fitting dan sanitary ware juga harus 
menentukan rancangan peningkatan operational excellence sehingga dapat meningkatkan produktivitas dan saya saing.

\section{II.DASAR TEORI}

Menurut Dewan Produktivitas Nasional (Husein, 2002: 9) menjelaskan bahwa produktivitas mengandung arti sebagai perbandingan antara hasil yang dicapai (output) dengan keseluruhan sumber daya yang digunakan (input). Menurut Muchdarsyah Sinungan (Produktivitas Apa dan Bagaimana, 2014 , 9) pentingnya arti produktivitas dalam meningkatkan kesejahteraan nasional telah disadari secara universal. Produktivitas itu penting sekali, karena pendapatan nasional arau GNP banyak diperoleh dengan meningkatkan keefektifan dan mutu tenaga kerja dibandingkan dengan melalui formasi modal dan penambahan kerja. Peningkatan produktivitas juga menghasilkan peningkatan langsung pada standar hidup.

Keunggulan operasi (operational excellence) adalah terus melakukan perbaikan kualitas barang atau jasa dengan cara meningkatkan kemampuan sumber daya manusia, mengurangi biaya yang tidak perlu dan meningkatkan fleksibilitas yang tinggi pada alat produksi yang dipakai, juga meningkatkan kecepatan proses, semua ini untuk mencapai keunggulan yang super. Ada 3 parameter yang harus dipenuhi untuk mencapai operational excellence seperti sudah dijelaskan diatas yaitu:

1. Manusia

2. Mesin / alat

3. Proses

Koordinasi yang kuat diantara 3 pilar diatas diperlukan dalam rangka mencapai keunggulan operasi secara keseluruhan.

Overall Equipment Effectiveness (OEE) adalah total pengukuran terhadap performance yang berhubungan dengan availability dari proses produktivitas dan kulitas. Pengukuran OEE menunjukkan seberapa baik perusahaan mengunakan sumber daya yang dimiliki termasuk peralatan, pekerja dan kemampuan untuk memuaskan konsumen dalam hal pengiriman yang sesuai dengan spesifikasi kualitas menurut konsumen.

Overall Equipment Effectiveness atau biasa kita kenal dengan singkatan OEE adalah matriks yang mengidentifikasi presentase waktu produktif dari keseluruhan waktu yang digunakan untuk menyelesaikan aktifitas produksi. Nilai OEE yang mencapai $100 \%$ artinya produksi berjalan dengan sempurna dan produktifitasnya maksimum. Artinya, lini produksi hanya menghasilkan produk yang $100 \%$ baik, dalam waktu yang sangat cepat sesuai alokasinya, tanpa ada down time.

Nilai atau skor OEE dihitung dengan mempertimbangkan tiga faktor, yaitu:

1. Availability: waktu produksi sebenarnya, dibandingkan dengan waktu produksi yang direncanakan. Jika nilai Availability 100\%, artinya proses selalu berjalan dalam waktu yang sesuai dengan waktu produksi yang telah direncanakan (tidak pernah ada down time).

2. Performance: artinya performa proses, apakah mampu memaksimalkan percepatan produksi. Jika nilai Performance 100\%, maka proses telah berjalan dengan kecepatan maksimal (secara teoretis, berdasarkan Ideal Cycle Time dan Total Pieces).

3. Quality: berkaitan dengan defect dan scrap. Nilai 100\% untuk Quality artinya produksi tidak menghasilkan produk cacat sama sekali.

Perhitungan Overall Equipment Effectiveness (OEE) menggunakan data dari "Enam Kerugian Besar (The Six Big Losses)", yaitu :

1. Availability, yang terdiri dari Breakdowns dan Setup/Adjustments

2. Performance, yang terdiri dari Small Stops dan Slow Running

3. Quality, yang terdiri dari Startup Defects dan Production Defect

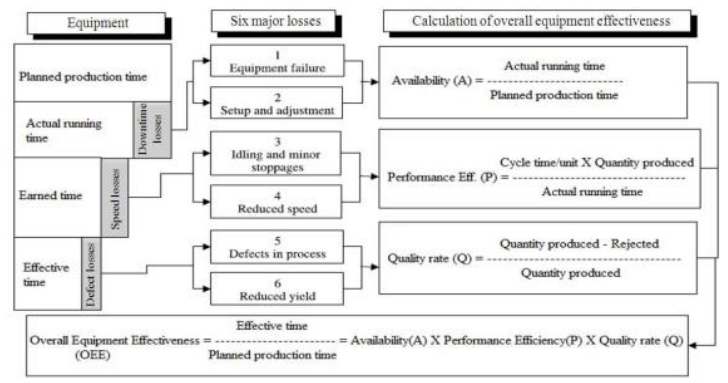

(sumber: K.G Eswaramurthi dan P.V Mohanram, American Jurnal of Applied Sciences, 2013)

Gambar 1. Perhitungan OEE

Tabel nilai OEE dapat dilihat pada tabel 1 dibawah ini. 
Tabel 1 Klasifikasi Nilai OEE

\begin{tabular}{|l|c|}
\hline \multicolumn{1}{|c|}{ OEE Faktor } & $\begin{array}{c}\text { Nilai Kelas } \\
\text { Dunia }\end{array}$ \\
\hline Availability & $90 \%$ \\
\hline Performance & $95 \%$ \\
\hline Quality & $99 \%$ \\
\hline $\begin{array}{l}\text { OVERALL EQUIPMENT } \\
\text { EFFECTIVENESS }\end{array}$ & $85 \%$ \\
\hline
\end{tabular}

(Sumber: Dari berbagai sumber dan diolah sendiri)

Ada metode baru yang diusulkan untuk menghitung efektivitas yang berbeda dari yang sudah ada. Dan faktor baru dikenal dengan Readiness, Availability of Facility, Changeover Efficiency, Availibility of Material, Availibility of Manpower, Performance Efficiency dan Quality Rate masuk kedalam perhitungan. Akhirnya perhitungan efektivitas yang sudah ada saat ini (OEE) dimodifikasi atau dirubah menjadi ORE (Overall Resource Effectiveness) yaitu perhitungan keseluruhan efektivitas sumber daya yang dimiliki oleh suatu organisasi perusahaan.

Pengukuran ORE mengarah fokus ke peningkatan yang diperlukan untuk meningkatkan efektivitas sistem manufaktur. ORE menyediakan panduan yang berguna untuk aspek dari proses produksi di mana kerugian dapat ditargetkan dimana diciptakan oleh sumber daya. Dalam rangka untuk memanfaatkan ukuran ORE efektif, itu harus dibuat meyakinkan dan memungkinkan untuk manufaktur yang berbasis lingkungan. Untuk ini, efektivitas nyata dari sistem manufaktur dihitung sepenuhnya menggunakan metode ORE. Itu pengukuran efektivitas menggunakan ORE cukup baik untuk meningkatkan efektivitas sumber daya. Hasil Penelitian menunjukkan bahwa metode yang diusulkan dari ORE akan membantu untuk organisasi hari ini untuk memulai perbaikan kegiatan terhadap peningkatan kinerja keseluruhan sumber dengan mengidentifikasi masalah persis (berdasarkan faktor yang diusulkan) dan dengan demikian mencapai keunggulan bisnis dengan pemanfaatan yang efektif dari sumber daya yang tersedia. Lebih lanjut, metrik ORE dapat digunakan sebagai acuan di berbagai tingkatan untuk mencapai standar kelas dunia.

Untuk ORE sendiri terdapat 7 faktor yang perlu dilakukan perhitungan:

1. Readiness ( R )

2. Availability of Facility ( Af )
3. Changeover Efficiency ( C )

4. Availability of Material ( Am )

5. Availability of Manpower (Amp)

6. Performance Efficiency ( P )

7. Quality Rate ( Q )

Metodologi baru membahas kerugian yang terkait dengan sumber daya (manusia, mesin, material dan metode). Pencantuman faktor-faktor baru memungkinkan kita untuk lebih rinci dalam mengklasifikasi sumber daya. Gambar 2.3 dibawah ini menunjukkan model dari Overall Resource Effectiveness (ORE).

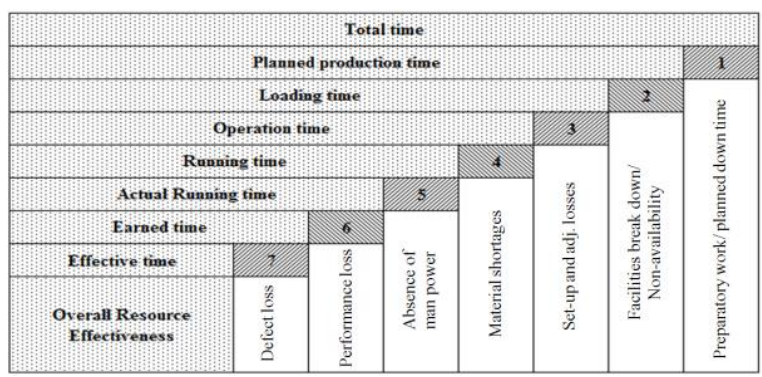

(Sumber: K.G. Eswaramurthi dan P.V Mohanrem, American Jurnal of Applied Sciences, 2013

Gambar 2. Model ORE

Jadi dalam ORE ini perhitungan dilakukan menyeluruh, yaitu semua sumber daya yang ada, sehingga dapat mengetahui keseluruhan efektivitas sumber daya yang dimiliki.

Metode perhitungan OEE dan ORE adalah sebagai berikut :

\section{Perhitungan Metode OEE}

Availability Rate (A)

$A=\frac{\text { Actual Running Time }}{\text { Planned Production Time }} \times 100 \%$

Performance Rate (P)

$P=\frac{\text { Cycle } \frac{\text { Time }}{\text { Unit }} \times \text { Quantity Produced }}{\text { Actual Running Time }} \times 100 \% \ldots$

Quality Rate $(\mathbf{Q})$

$Q=\frac{\text { Quantity Produced }- \text { Rejected }}{\text { Quantity Produced }} \times 100 \%$.

Overall Equipment Effectiveness

$\mathrm{OEE}=$ Availability Rate $\times$ Performance Rate $x$ Quality Rate

\section{Perhitungan Metode ORE}

Untuk perhitungan ORE dilakukan dengan

tahapan perumusan sebagai berikut :

Readiness $(R)$

$R=\frac{\text { Planned Production Time }}{\text { Total Time }}$

Total Time $=$

Waktu shift atau periode waktu yang diputuskan oleh Managemen.

Planned Production Time $=($ Waktu Total Waktu Tunggu yg direncanakan) 
Waktu Tunggu yang direncanakan meliputi:

1. Persiapan pekerjaan, seperti pembersihan, pemeriksaan mesin, pemeriksaan part, pemberian pelumas, pengencangan

2. Meeting, audit, pelatihan pekerja

3. Pembuatan sampel untuk R\&D atau pengerjaan barang-barang sampel pengembangan.

Availibility of Facility ( Af )

Af $=\frac{\text { Loading Time }}{\text { Planned Production Time }}$

Loading Time $=$ Waktu produksi yang direncanakan - Waktu fasilitas berhenti

Waktu fasilisitas berhenti meliputi:

1. Waktu mesin berhenti

2. Alat pendukung dan jig tidak atau belum tersedia

3. Alat ukur atau gauge tidak atau belum tersedia

Change Over Efficiency ( C )

$C=\frac{\text { operation Time }}{\text { Loading Time }}$...

Operation Time $=$ Waktu yang tersediaWaktu Set-Up dan Adjusment.

Set-up dan adjustment meliputi

1. Waktu mengganti alat bantu (tools), des, jigs dan perlengkapan lain

2. Waktu penyesuaian kecil setelah perubahan alat.

Availability of Material ( Am )

Am $=\frac{\text { Running Time }}{\text { Operation Time }}$

Running Time Waktu kerja - Kekuragan

Material

Kekurangan material meliputi

1. Tidak tersedianya bahan baku, barangbarang cepat habis, dan barang-barang unit.

2. Tidak tersedianya material untuk diproses

Availability of Manpower ( Amp )

Amp $=\frac{\text { Aktual Running Time }}{\text { Running Time }}$

Actual Running Time = Waktu Kerja - Waktu

Tenaga Kerja Tidak Masuk

Tenaga kerja tidak masuk meliputi :

1. Ijin, meninggalkan pekerjaan

2. Diskusi dengan pengawas atau kepala regu

3. Ijin terkait kesehatan (sakit)

Performance Efficiency ( $P$ )

$P=\frac{\text { Earned Time }}{\text { Actual Running Time }}$

Earned Time $=$ Waktu proses / unit X Jumlah

Produksi

Quality Rate ( Q )

$Q=\frac{\text { Quantity of Parts Accepted }}{\text { Quantity of Parts Produced }}$

Quantity of Part Accepted = Jumlah Produksi Jumlah reject..

\section{III.METODE PENELITIAN}

\section{A. Identifikasi Masalah}

Proses dimulai dengan identifikasi masalah yang diuraikan menjadi daftar gejala, analisis dan sintesa dari gejala, kemudian menentukan akar masalah sehingga dapat merumuskan akar masalah. Dilanjutkan dengan menentukan tujuan penelitian, manfaat penelitian dan ruang lingkup penelitian. Tahap-tahap identifikasi masalah secara bertahap dilakukan sebagai berikut :

B. Latar Belakang dan Perumusan Masalah

Posisi tingkat daya saing Indonesia berada diposisi 37 dunia dan posisi 4 di ASEAN. Pertumbuhan ekonomi Indonesia tahun menurun dalam 6 tahun terakhir. Hasil produk produksi dalam negeri tidak kompetitif dan mahal. Untuk itu perlu dilakukan analisa mengenai efektivitas proses dan menentukan rancangan peningkatan operational excellence sehingga dapat meningkatkan produktivitas dan daya saing. Karena produktivitas berkaitan dengan daya saing.

\section{Tujuan dan Manfaat Penelitian}

Tujuan yang ingin dicapai pada penelitian ini adalah dapat merumuskan perancangan peningkatan operational excellence untuk meningkatkan produktivitas dan daya saing industi manufaktur. Untuk perusahaan tempat dilakukan penelitian diharapkan dapat dipakai untuk proses peningkatan produktivitas dan mencapai operational excellence.

\section{Studi Literatur}

Pada proses ini dilakukan dengan pencarian informasi mengenai konsep-konsep dari teoriteori operational excellence, OEE, ORE, proses wawancara dan pengolahan data yang akan dipakai untuk penelitian ini. Teori-teori tersebut bisa didapat dari buku-buku atau jurnal-jurnal yang mempunyai hubungan dengan penelitian yang sedang dilakukan

\section{E. Studi Lapangan}

Studi lapangan dilakukan dengan melihat kondisi proses yang ada dilapangan atau dilini produksi. Sehingga peneliti mendapatkan gambaran yang baik mengenai kondisi lapangan yang akan diteliti.

\section{F. Persiapan Penelitian}

Tahap ini dimulai dengan mengumpulkan data pendukung untuk perhitungan OEE dan ORE yaitu data kinerja perusahaan.

1. Data kinerja perusahaan yaitu hasil penelusuran data-data yang ada 
diperusahaan yang berhubungan dengan apa yang diperlukan untuk penelitian ini. Data-data yang diperoleh kemudian diolah untuk mendapatkan nilai :

a. Availability (Ketersediaan Waktu)

b. Performance (Kinerja)

c. Quality (Kualitas)

d. Readiness (Kesiapan)

e. Availability of Facility (Ketersediaan Fasilitas)

f. Changeover Efficiency (Efisiensi Peralihan Proses)

g. Availability of Material (Ketersediaan Material)

h. Availability of Manpower (Ketersediaan Karyawan)

i. Nilai OEE

j. Nilai ORE

2. Kemudian untuk menambahkan data pendukung dan menentukan penyebab dan rencana tindakan dilakukan dengan proses wawancara dan diskusi dengan pihak-pihak terkait (key person) atau orang-orang mengetahui detail dari setiap proses dan pengambil keputusan di PT. Surya Toto Indonesia, Tbk.

\section{G. Pengukuran dan Pengolahan Data}

Teknik pengolahan data dilakukan dengan menggunakan metode Overall Equipment Effectiveness (OEE) dan metode Overall Resource Effectiveness (ORE). Ada perbedaan antara perhitungan OEE dan ORE. Pada perhitungan OEE tidak ada metrik atau metode terpisah untuk memantau kerugian akibat nonketersediaan tenaga kerja dan bahan (komponen, sub-rakitan dan WIP) yang juga sangat penting untuk efektivitas dari sistem manufaktur. Faktor OEE yang ada tidak cukup untuk penilaian kerugian secara individual di manufaktur sistem.

Metode perhitungan OEE dan ORE seperti yang sudah disampaikan pada BAB III

\section{H. Penentuan Penyebab Masalah}

Proses pengumpulan untuk mngetahui penyebab masalah selain dari proses pengamatan, perhitungan juga bisa dapat dari proses wawancara atau interview. Dalam proses ini data, informasi atau keterangan diperoleh secara langsung dari responden dengan cara tatap muka dan bercakap-cakap.

Menurut M.Nazir (Metodologi Penelitian, 2005), definisi dari wawancara adalah proses memperoleh keterangan untuk tujuan penelitian dengan cara Tanya jawab, sambil bertatap muka antara si penanya atau pewawancara dengan si penjawab atau responden dengan menggunakan alat yang dinamakan interview guide (panduan wawancara).

Walaupun wawancara adalah proses percakapan yang berbentuk tanya jawab dengan tatap muka, wawancara adalah proses pengumpulan data untuk suatu penelitian. Menurut M.Nazir (Metodologi Penelitian, 2005), beberapa hal dapat membedakan wawancara dengan percakapan sehari-hari, antara lain :

1. Pewawancara dan responden biasanya belum saling mengenal sebelumnya.

2. Responden selalu menjawab pertanyaan

3. Pewawancara selalu bertanya

4. Peawawancara tidak menjuruskan pertanyaan kepada suatu jawaban, tetapi harus bersifat netral.

5. Pertanyaan yang ditanyakan mengikuti panduan yang telah dibuat sebelumnya. Pertanyaan panduan ini dinamakan interview guide.

Wawancara merupakan proses interaksi antara pewawancara dengan responden. Dalam hal ini bisa saja dalam prosesnya dimana wawancara ini adalah bagian pengumpulan data bagi pewawancara, tetapi tidak demikian bagi responden. Untuk itu sebelummemulai proses wawancara maka pewawancara perlu menerangkan tujuan proses wawancara tersebut. Menurut M.Nazir (Metodologi Penelitian, 2005), umumnya urut-urutan prosedur dalam memulai wawancara adalah sebagai berikut:

1. Menerangkan kegunaan serta tujuan dari penelitian

2. Menjelaskan mengapa responden terpilih untuk diwawancari

3. Menjelaskan institusi atau badan apa yang melaksanakan penelitian tersebut

4. Menerangkan bahwa wawancara tersebut merupakan suatu yang confidential.

\section{Analisa dan Interprestasi Hasil}

Pada proses ini dilakukan analisa dari hasil proses perhitungan OEE, ORE dan hasil proses wawancara. Proses analisa dengan menggunakan metode 4M1L (Manusia, Metode, Mesin Material dan Lingkungan). Analisa ini dilakukan untuk mengetahui penyebab dari masalah atau keberhasilan dari suatu proses yang dilakukan. 
Setelah didapat hasil maka dilakukan proses analisa sebab akibat (diagram Fishbone). Proses analisa ini bertujuan untuk mencari lebih dalam mengenai akar masalah dan tindakan yang perlu dilakukan

Kemudian langkah terakhir untuk mengambil keputusan tindakan apa yang perlu dilakukan terlebih dulu atau urutan tindakan yang perlu dilakukan mana dilakukan dengan metode Nominal Group Technique (NGT).

Dari urutan analisa diatas maka dapat disimpulkan rancangan tindakan perbaikan (improvement) yang bisa dilakukan untuk dapat meningkatkan operational excellence, sehingga tercapai produktivitas dan daya saing.

\section{J. Analisa Sebab Akibat (Diagram Fishbone)}

Diagram ini disebut juga diagram tulang ikan (fishbone chart) dan berguna untuk memperlihatkan faktor-faktor utama yang berpengaruh pada kualitas dan mempunyai akibat pada masalah yang kita pelajari, Prinsip yang digunakan untuk membuat diagram sebab akibat ini adalah sumbang saran atau brainstorming. Diagram sebab akibat ini pertama kali dikembangkan pada tahun 1950 oleh seorang pakar kualitas dari Jepang, Dr. Kaoru Ishikawa yang menggunakan uraian grafis dari unsur-unsur proses untuk menganalisis sumber-sumber potensial dari penyimpangan proses. Faktor-faktor penyebab utama ini dapat dikelompokkan dalam Material/Bahan Baku, Machine/Mesin, Man/Tenaga Kerja, Method/Metode, Environment/Lingkungan.

Selain definisi mengenai fishbone diatas, analisa fishbone juga berarti:

1. Metode sederhana yang dapat dipergunakan untuk menelusuri penyebab suatu permasalahan yang terjadi

2. Dalam prosesnya melibatkan semua orang

3. Dasarnya adalah prinsip bahwa pemikiran yang bersumber dari orang banyak lebih baik dari 1 orang.

4. Dinamakan diagram tulang ikan karena bentuk dari diagram ini seperti tulang ikan, dengan permasalahan sebagai kepalanya, dan penyebab-penyebab yang ada sebagai duri-durinya.

Dengan adanya diagram fishbone (tulang ikan)/Cause and Effect (Sebab Akibat) ini sebenarnya member banyak sekali keuntungan bagi dunia manufaktur. Selain dapat memecahkan masalah kualitas yang menjadi perhatian penting perusahaan, masalah-masalah lainnya juga dapat terselesaikan. Masalah-masalah lainnya yang ada didunia industry manufaktur khususnya antara lain adalah :

1. Keterlambatan proses produksi

2. Tingkat defect (cacat) produk yang tinggi

3. Output lini produksi yang tidak stabil yang akibatnya rencana produksi menjadi kacau.

4. Produktivitas yang tidak tercapai

5. Komplain pelanggan terus berulang

Dari uraian analisis fishbone diatas, maka diagram analisis fishbone dapat juga berfungsi sebagai catatan penelitian

\section{K. NGT (Nominal Group Tehnique)}

Nominal Group Technique (NGT) atau Teknik Kelompok Nominal adalah salah satu teknik peran serta dalam pengambilan keputusan yang efektif. Teknik ini dikembangkan oleh Dellbecq dan Van de Ven pada tahun 1968 (Delbecq, et all., 1975), dimaksudkan sebagai suatu cara untuk mengumpulkan pandangan dan penilaian perorangan dalam suasana ketidakpastian dan ketidaksepakatan mengenai inti persoalan suatu masalah, lalu mencari jalan penyelesaian yang terbaik. Cara perhitungannya sebagai berikut:

NGT

$$
\geq \frac{\text { Jum Penyebab X Jum Anggota Penilai }}{2}
$$$$
+1
$$

Cara perhitungan nominal group technique ini adalah dengan cara :

1. Merekap hasil analisa penyebab masalah yang didapat dari observasi atau proses wawancara kedalam tabel atau matrik.

2. Kemudian matrik ini diserahkan kepada penilai. Penilai ini bisa key person yang sudah kita wawancarai atau orang-orang yang memang kita butuhkan masukannya untuk menentukan penyebab dominan.

3. Penilai kemudian memberikan nilai sesuai dengan bobotnya. Bobot nilai yang diberikan adalah maksimal sesuai dengan jumlah masalah yang didapat, contoh dari hasil observasi atau wawancara ada 18 masalah, maka penentuan bobot nilainya yang terbesa adalah 18 sampai dengan yang terkecil adalah 1 .

4. Hitung batasan nilai NGT, misalnya jumlah masalah adalah 18 masalah dan jumlah penilai adalah 8 orang maka nilai NGT-nya adalah :

$$
N G T \geq \frac{18 \times 8}{2}+1=73
$$


Dengan demikian nilai minimal penyebab dikatakan dominan adalah 73 ketas. Dibawah 73 tidak disebut penyebab dominan.

Untuk mendapatkan hasil yang diinginkan dilakukan proses perhitungan dengan menggunakan metode OEE, ORE, wawancara, pencarian penyebab masalah dengan diagram Fishbone dan penentuan penyebab dominan dengan metode NGT.

\section{A. Metode}

Metode yang sudah umum atau pernah dipublikasikan cukup diacu saja. Bilamana terdapat sub-bab ditulis dengan huru $A, B, C, . . d s t$. Dengan huruf times new roman, size 11, bold dan huruf capital diawal kata. (satu baris kosong / enter 1 kali)

\section{IV.HASIL DAN PEMBAHASAN}

Dari hasil pengukuran dan perhitungan OEE (Overall Equipment Effectiveness) juga perhitungan ORE (Overall Resource Effectiveness) didapat hasil berikut, bisa dilihat pada tabel 2 berikut:

Tabel 1. Rekapitulasi Effectiveness Factor

\begin{tabular}{|l|c|c|c|c|}
\hline \multicolumn{1}{|c|}{ EFFECTIVENESS FACTOR } & PB 1 & PB 2 & PB 3 & ASSY \\
\hline \hline QUALITY & $99.44 \%$ & $91.57 \%$ & $99.39 \%$ & $100.00 \%$ \\
\hline AVAILABILITY & $92.08 \%$ & $95.24 \%$ & $94.02 \%$ & $96.46 \%$ \\
\hline PERFORMANCE EFFICIENCY & $80.67 \%$ & $75.20 \%$ & $85.95 \%$ & $85.57 \%$ \\
\hline READINESS & $102.12 \%$ & $99.36 \%$ & $103.83 \%$ & $102.28 \%$ \\
\hline AVAILABILITY OF FACILITY & $99.97 \%$ & $99.71 \%$ & $99.99 \%$ & $100.00 \%$ \\
\hline CHANGEOVER EFFICIENCY & $97.35 \%$ & $99.13 \%$ & $98.65 \%$ & $100.00 \%$ \\
\hline AVAILABILITY OF MATERIAL & $100.00 \%$ & $100.00 \%$ & $100.00 \%$ & $100.00 \%$ \\
\hline AVAILABILITY OF MANPOWER & $94.62 \%$ & $96.34 \%$ & $96.06 \%$ & $96.46 \%$ \\
\hline $\begin{array}{l}\text { OVERALL EQUIPMENT } \\
\text { EFFECTIVENESS }\end{array}$ & $73.86 \%$ & $\mathbf{6 5 . 5 8 \%}$ & $80.32 \%$ & $\mathbf{8 2 . 5 4} \%$ \\
\hline $\begin{array}{l}\text { OVERALL RESOURCE } \\
\text { EFFECTIVENESS }\end{array}$ & $\mathbf{7 5 . 4 3 \%}$ & $\mathbf{6 5 . 1 5} \%$ & $\mathbf{8 4 . 0 4 \%}$ & $\mathbf{8 4 . 4 2 \%}$ \\
\hline
\end{tabular}

(sumber: pengolahan data sendiri)

Dari tabel nilai OEE dan ORE diketahui bahwa nilai OEE dan ORE dibawah dari standar world class yaitu $85 \%$.

Dari hasil perhitungan OEE dan ORE diatas, bahwa rendahnya nilai OEE dan ORE lebih dominan disebabkan oleh faktor performance. Dan seperti juga sudah dijelaskan bahwa performance efficiency adalah bagaimana efektivitas suatu peralatan dalam beroperasi menghasilkan barang. Efektivitas mesin bukan hanya tanggung jawab dari mesin. Tetapi banyak faktor yang membuat suatu mesin tidak efektiv dalam berproses. Faktorfaktor yang berpengaruh dalam efektivitas suatu mesin dalam beroperasi adalah yang berhubungan dengan mesin dan prosesnya, diantaranya manusia, metode, mesin itu sendiri, material yang digunakan, juga lingkungan, dengan kata lain adalah 4M1L.

\section{A. Diagram Sebab Akibat (Fishbone)}

Rekapitulasi hasil diagram sebab akibat sudah dibuat tabel 4M1L, dan bisa dilihat pada tabel 2 dibawah ini,

Tabel 2. Hasil Diagram Sebab Akibat

\begin{tabular}{|c|c|c|}
\hline No & & MASALAH \\
\hline 1 & \multirow{5}{*}{ Manusia } & Skill/Kemampuan belum merata \\
\hline 2 & & Komunikasi (HORENSO) belum berjalan baik \\
\hline 3 & & $\begin{array}{l}\text { Kedisiplinan dalam pemakaian waktu kerja masih kurang baik } \\
\text { (Moral) }\end{array}$ \\
\hline 4 & & Regenerasi belum berjalan baik \\
\hline 5 & & Kelebihan sumber daya manusia \\
\hline 6 & \multirow{5}{*}{ Metode } & Monitoring terhadap pelaksanaan SK/DIK masih kurang \\
\hline 7 & & $\begin{array}{l}\text { Forecase tidak berjalan shg pmbuatan rencana menjadi } \\
\text { kurang baik }\end{array}$ \\
\hline 8 & & Pemilihan supplier masih kurang baik \\
\hline 9 & & Adanya perbedaan cycle time untuk barang yang mirip \\
\hline 10 & & $\begin{array}{l}\text { Belum adanya standar waktu untuk proses overhole mesin } 2 \\
\text { Lama }\end{array}$ \\
\hline 11 & \multirow{3}{*}{ Material } & Kualitas barang dari supplier tidak stabil \\
\hline 12 & & Keterlambatan barang dari supplier sering terjadi \\
\hline 13 & & Suplai barang dari seksi sebelumnya kadang terlambat \\
\hline 14 & \multirow{3}{*}{ Mesin/Alat } & $\begin{array}{l}\text { Sulit memprediksi kerusakan mesin, sehingga berdampak } \\
\text { pada penyediaan spare part }\end{array}$ \\
\hline 15 & & Usia mesin rata-rata sudah diatas 10 th \\
\hline 16 & & Masih ada digunakan mesin2 yang konvensional (lama) \\
\hline 17 & \multirow{2}{*}{ Lingkungan } & Layout mesin masih kurang \\
\hline 18 & & $5 \mathrm{~S}$ masih kurang baik dibeberapa seksi \\
\hline
\end{tabular}

(sumber: pengolahan data sendiri)

\section{B. Penentuan Penyebab Dominan}

Dari hasil diatas maka dilakukan analisa dengan perhitungan NGT untuk mengetahui penyebab yang paling dominan, hasilnya NGT bisa dilihat pada tabel 3 dibawah ini:

Tabel 3. Hasil Diagram Sebab Akibat

\begin{tabular}{|c|c|c|}
\hline NO & & PENYEBAB \\
\hline 1 & Manusia & $\begin{array}{l}\text { Kedisiplinan dalam pemakaian waktu kerja masih } \\
\text { kurang baik (Moral) }\end{array}$ \\
\hline 2 & Material & $\begin{array}{l}\text { Suplai barang dari seksi sebelumnya kadang } \\
\text { Terlambat }\end{array}$ \\
\hline 3 & Manusia & Skill/Kemampuan belum merata \\
\hline 4 & Material & Kualitas barang dari supplier tidak stabil \\
\hline 5 & Manusia & Regenerasi belum berjalan baik \\
\hline 6 & Metode & $\begin{array}{l}\text { Forecase tidak berjalan shg pmbuatan rencana } \\
\text { menjadi kurang baik }\end{array}$ \\
\hline 7 & Material & Keterlambatan barang dari supplier sering terjadi \\
\hline 8 & Metode & Pemilihan supplier masih kurang baik \\
\hline 9 & Metode & $\begin{array}{l}\text { Belum adanya standar waktu untuk proses } \\
\text { overhole mesin } 2 \text { lama }\end{array}$ \\
\hline 10 & Manusia & Komunikasi (HORENSO) belum berjalan baik \\
\hline 11 & Mesin/Alat & $\begin{array}{l}\text { Sulit memprediksi kerusakan mesin, sehingga } \\
\text { berdampak pada penyediaan spare part }\end{array}$ \\
\hline
\end{tabular}

Dari hasil penentuan penyebab dominan diperoleh manusia menjadi penyebab dominan dengan 4 penyebab, 3 penyebab material, 3 penyebab metode dan 1 yang disebabkan oleh mesin. Hasil menunjukkan bahwa manusia memegang peran dalam menentukan rendahnya produktivitas atau performance efficiency yang terjadi. Walaupun secara perhitungan availability of manpower nilainya cukup tinggi yaitu diatas 95\%. Tetapi karena moral dan kemampuan yang tidak merata maka membuat produktivitas masih rendah. 


\section{V.KESIMPULAN}

Berdasarkan penelitian yang dilakukan dengan melakukan analisa hasil perhitungan overall resource effectiveness dan overall equipment effectiveness dapat disimpulkan sebagai berikut:

1. Diketahui nilai effektivitas proses (OEE dan ORE) PT Surya TOTO Indonesia adalah sebagai berikut:

- Berdasarkan 3 faktor OEE (Avalilability, Performance Efficiency dan Quality) dan 7 faktor ORE (Readiness, Availability of Facility, Changeover Efficiency, Availability of Material, Quality, dan Performance Efficiency)

- $\quad$ Pabrik 1, nilai OEE adalah $73.86 \%$ dan nilai ORE adalah $75.43 \%$ (standar world class $85 \%$ ) dan penyebab rendahnya nilai OEE dan ORE adalah nilai performance efficiency sebesar $80.67 \%$ (standar world class adalah 95\%)

- $\quad$ Pabrik 2, nilai OEE sebesar $65.58 \%$ dan nilai ORE sebesar $65.15 \%$ (standar world class $85 \%$ ). Rendahnya nilai OEE dan ORE disebabkan karena rendahnya nilai quality $91.57 \%$ (standar world class 99\%) dan nilai performance efficiency sebesar $75.2 \%$ (world class $95 \%$ ).

- Pabrik 3, nilai OEE sebesar $80.32 \%$ dan nilai ORE sebesar $84.04 \%$ (standar world class $85 \%$ ). Rendahnya nilai OEE dan ORE disebabkan karena rendahnya nilai performance efficiency sebesar $85.95 \%$ (world class $95 \%$ ).

- Pabrik Assembling, nilai OEE sebesar $82.54 \%$ dan nilai ORE sebesar $84.42 \%$ (standar world class $85 \%$. Rendahnya nilai OEE dan ORE disebabkan karena rendahnya nilai quality $91.57 \%$ (standar world class 99\%) dan nilai performance efficiency sebesar $75.2 \%$ (world class $95 \%$ ).

2. Masalah yang menjadi penyebab utama rendahnya nilai performance efficiency adalah :

- Faktor Manusia, disebabkan karena kondisi moral yang kurang baik dan kemampuan yang tidak merata.

- Faktor Material , disebabkan karena suplai barang dari supplier dan seksi sebelumnya kadang terlambat.
Kemudian kualitas barang dari supplier tidak stabil.

- Faktor Metode, disebabkan karena pembuatan rencana kurang baik karena forecase tidak berjalan, metode pemilihan supplier masih kurang baik. Kemudian belum adanya standar waktu untuk pelaksanaan overhole.

- Faktor Mesin/Alat, disebabkan oleh kesulitan memprediksi keserusakan mesin sehingga berdampak pada penyediaan spare part.

3. Untuk meningkatkan performance efficiency perlu dilakukan perbaikan sebagai berikut :

A. Manusia

Peningkatan moral dan kemampuan (skill) karyawan dengan cara, pelatihan atau pendidikan sesuai kebutuhan, melakukan cross training agar kemampuan bertambah. Meningkatkan komunikasi atasan dengan bawahan (top down) juga bawahan dengan atasan (bottom up) agar semua informasi bisa berjalan dengan baik.

B. Material

Melakukan pemeriksaan kualitas barang secara berkala untuk barang hasil produksi supplier, saat ini proses pemeriksaan hanya dilakukan oleh bagian QC. Untuk mengantisipasi keterlambatan pengiriman material dari supplier karena permintaan tinggi maka dibuat stok penyangga (buffer stock) disupplier.

C. Metode

Tindakan untuk metode adalah perbaikan proses pembuatan rencana dimana melakukan optimalisasi penggunaan software SAP, kemudian perbaikan prosedure dalam proses pemilihan supplier terhadap mutu dan kesamaan sistem dengan yang dilakukan di PT Surya Toto Indonesia.

Isi kesimpulan memuat ringkasan yang hendak dicapai pada tujuan penelitian.

\section{DAFTAR PUSTAKA}

Ansori N, Mustajib I.M, "Sistem Perawatan Terpadu", Graha Ilmu, Yogyakarta, 2013.

Chaidir, Alek Julius, 2010, "Analisa Peluang Kapastitas Falisitas Produksi KantongSemen PT XYZ Melalui Evalusai 
Kinerja Pemeliharaan Menggunakan Overall Equipment Effectiveness (OEE) dan Overall Line Effectiveness (OLE)", Tesis Nasional, Fakultas Teknik, Program Studi Teknik Industri, Universitas Indonesia

Hidayatno, 2008, Operational Excellence,

Blogs,https://hidayatno.wordpress.c om/2008/01/30/operationalexcellence-operasional-terbaik

Horhan, Florian, 2013, "Opertional Excellence to Increase a Companies' Business Value in the Aircraft Industry", Master Thesis, Fachhochschul-

Masterstudiengang

Wirtschaftsingenieur.

IBM, 2008, Operational Excellence In Manufacturing: How to win at the margin with business intelligence, Information Management

Kurniawan. F. "Manajemen Perawatan Industri, Teknik dan Aplikasi. Graha Ilmu, Yogyakarta, 2013.

K.G Eswaramurthi and P.V Mohanram, 2013, Improvement of Manufacturing Performance Measurement System Evaluation of Overall Resource Effectiveness, American Journal of Applied Sciences, 10 (2): 131_138, 2013

Nazir. M, 2005, Metode Penelitian, Ghaila Indonesia, Bogor.

Raguram, R, 2014, Implementation of Overall Equipment Effectiveness (OEE), Journal of Scientific Research 20 (5): 567-576, 2014, Departement of Mechanical Engineering, Bharath University, India.

Sinungan, M, 2014, Produktivitas, Apa Dan Bagaimana, Bumi Aksara, Jakarta.

Sukwandi, Roland, 2007, Analisis Perbedaan Antara Faktor-Faktor Kinerja Perusahaan Sebelum dan Sesudah Menerapkan Strategi TPM ( Studi Kasus pada PT. Hartono Istana Teknologi Divisi Produk Home Appliances)

Syarif, Syahrizal, 2010, Pengukuran Overall Equipment Effectiveness (OEE) Dengan Labview 8.5 Sebagai Pengendali Maintenance, Tesis Nasional, Fakultas

Wenda Enngatiani, Usman Effendi, Shyntia Atica Putri, 2012, Evaluasi Keefektifan Program OE (Operational Excellence) Dengan Metode Overall Equipment
Effectiveness (OEE) (Studi Kasus di PT Coca Cola Amatil Indonesia Surabaya. 
